\title{
NATURE CONSERVANCY
}

\author{
REPORT FOR 1955-56
}

$\mathrm{D}$ RING the year ended September 30, 1956 , covered by its seventh annual report*, the Nature Conservancy was able to pursue its research and development programme without serious distraction, and the level of grant-in-aid has been increased from $£ 202,000$ in $1954-55$ and $£ 203,400$ in 1955-56 to $£ 280,000$ in $1956-57$. While this increase is insufficient to enable the Commission to overtake the accumulation of several years arrears, it allows the worst consequences of earlier financial stringencies to be corrected, although scientific programmes had again to be restricted and work on the development and maintenance of reserves postponed. The internal organization has been overhauled so as to strengthen the Conservation Branch as the central executive organ for the future and enable it to cope with the increasing load of advisory and liaison activities and of reserve management and the related experimental work.

Besides the accounts, which record a general expenditure of $£ 186,587$ and capital expenditure of $£ 19,035$, appendixes include a list of committees and their ternus of reference and membership, as well as lists of establishments of the Conservancy and of research grants during the year. Tribute is paid in the report to the great services of Sir Arthur Tansley, which the Conservancy proposed to commemorate by placing a suitably inseribed sarsen stone by the great yew grove at Kingley Vale Nature Reserve. To strengthen the Conservancy's link with the work of the scientific staff and the fulfilment of their programme, the Scientific Policy Committee created a Panel of Visitors which spent several days at the research stations, discussing progress and problems with the scientific staff. This detailed review has confirmed both the soundness of the scientific programme and the competence of the scientific officers to execute it.

In scientific research the year was one of consolidation and progress within existing programmes. At the Moor House Nature Reserve a number of species of plants from the Lake District and from Scotland have been planted in the sheep enclosures at the western end of the Reserve in an attempt to re-create the types of plant community which may have existed before the introduction of intensive grazing. Data for two full years obtained from the weirs, installed to measure run-off for catchment areas covered with peat, indicate that after heavy rainfall the peak flow from the catchment area covered by natural sphagnum bog is less and occurs later than that from an area of which parts have been burned, surface-drained or eroded. In studies on peat and peat vegetation, attention is being directed to aspects of fertility and nutrient turnover, with special reference to the role of phosphorus as a possible limiting factor. From investigations on the grasslands and soils of Snowdonia it appears that those derived from volcanic ashes are the most subject

* Report of the Nature Conservancy for the year ended 30th September, 1956. Pp. $\mathbf{v}+82+12$ plates. (London: H.M. Stationery
Office, 1956.) 4s. $6 d$. net. to erosion, but they bear the better kinds of mountain grass and carry the greater number of sheep per acre.

At Benin Eighe, experiments have continued on the fundamental aspects of pine-wood ecology, and in the Cairngorms investigations are in progress into factors affecting the natural regeneration and persistence of the Scots pines, while the experiments at Moor House on the re-establishment of high-level woodland continue to yield interesting results. Work at Merlewood is concerned with the behaviour of woodland as a whole in relation to soil fertility, water balance and biological productivity, and also with the detailed ecology of individual woodlands. Similar intensive studies are being carried out in the Roudsea Wood Nature Reserve, including, the study of natural regeneration; and in view of the severe damage in the oak wood from attacks of Tortrix viridana cater. pillars, future investigations will be aimed at develop. ing control measures suitable for use in nature reserves, where, if insecticides are to be used, a high specificity and short residual action are desirable to avoid excessive damage to the insect fauna as a whole.

Studies on litter breakdown and the associated fauna of both soil and litter continued at Merlewood, and at Roudsea Wood field experiments have been set up to determine the rate of disappearance of the various types of leaves on the different soil types, while intensive laboratory studies have been made on the estimation of amino-acid contents in extracts of fallen leaves and on extracting the nematodes. A statistical procedure used to investigate the composition of the soil fauna in relation to different kinds of woodland yielded results suggesting that a characteristic fauma has developed in association with the native broadleaved woodlands, whereas the coniferous woodlands have as yet only the general woodland fauna. Research continued in the Forestry Commission's plantations in the Carron valley, Stirlingshire, on the part voles play as consumers of the grasses of upland areas, and investigations are being maintained into the repercussions on vegetation and animal life of the reduction in rabbit numbers.

In coastal regearch at Bridgwater Bay new evidence was obtained that cord grass (Spartina townsendii) virtually arrests the movement of shingle, and the controlled sheep-grazing experiments on Spartina townsendii marsh suggest that a properly managed grazing regime favours the development of a fine marsh turf valuable as a feeding ground for stock and wildfowl. Experiments in co-operation with the Isotope Division of the United Kingdom Atomic Energy Research Establishment and the Department of Geography, University of Cambridge, have demonstrated the possibility of using radioactive isotopes to trace the movement of coarse beach material in the offshore zone at Scolt Head Island. Measurements of the dune vegetation on transects extending half a mile at Newborough Warren, Anglesey, have shown that, since the loss of rabbits through myxomatosis, the taller and more drought-tolerant species have increased at the expense of the shorter and 
less drought-tolerant species. Some progress was made in preparing a full account of the first three years general climatological observations at Moor House, and this chapter of the report includes a list of scientific publications during the year.

The report contains a nèw section dealing with scientific advisory services, which have increased greatly and are expected to expand further. Advice on land use was given to the Royal Commission on Common Land and a programme for short-term research on grey seals in relation to salmon fisheries has been initiated after discussions between the Conservancy, the Ministry of Agriculture, Fisheries and Food and the Scottish Home Department. The scientific staff have investigated the vegetation of the reindeer reserve in relation to the feeding habits of the herd, and are to study in more detail the effects of the grazing of reindeer on the mountain pastures, particularly the rate of re-growth of lichens on the grazed areas. 'The final assessment of plots sprayed with selective weed-killers for four consecutive years indicates that the use of selective weed-killers for blanket spraying on this type of community is of limited value in improving visibility for road users, but that they could be used against obnoxious weeds which occur in localized strands, for example, Cirsium and Rumex species, and for clearing scrub. Following an initial discussion in September 1955, the Nature Conservancy is to call a meeting of those engaged in ecological research touching any aspect of moor burning. The Conservancy is also concerned about the harmful effects which uncontrolled and unessential burning may inflict on both the flora and fauna and on soil fertility and is investigating the development of an effective alternative method of controlling unwanted woody vegetation which will not cause indirect damage to other plant and animal life.

'I he rate of acquisition of new national nature reserves continued to fall below what was hoped, but the twelve new reserves established during the year and additions to four existing reserves brought the total to 47 reserves and 82,662 acres, compared with 35 reserves and 79,035 acres on September 30 , 1955 , of which little more than one-third is owned by the Conservancy. Following notification of local planning authorities of sites of special scientific interest under Section 23 of the Act in England and Wales, seventeen counties in Scotland have now been covered, the fifty-eight sites notified involving an approach to ninety-seven different owners. Despite the publicity given by voluntary societies, much remains to be done to secure observance of the general principle of the Protection of Birds Act, 1954, and the Conservancy has advanced proposals for the creation of a number of sanctuaries under the Act. A brief report is included on the Humber Wildfowl Refuge, the first sanctuary in which public access has been legally regulated in the interests of the wildfowl. The statement regarding the buzzard issued to the press in March 1956 is also included, the facts in which have since been largely confirmed by the 1956 Buzzard Survey.

Only seven new grants, amounting to $£ 11,000$, were awarded during the year and no new applications can be considered before September 1957, to take effect in 1958-59. Excellent progress was made with the National Collection of Nature Photographs, which now includes some two hundred photographs.

\section{NATIONAL PARKS COMMISSION}

\section{REPORT FOR 1955-56}

$T$ HE seventh annual report of the National Parks Commission*, covering the year ended Septem. ber 30,1956 , records no designations of new National Parks, although the Order for the Northumberland National Park was confirmed, with slight modification. The Minister's decision on proposals for the Brecon Beacons National Park is still awaited, and the Commission has now reached the conclusion that designation of the South Downs as a 'park' would not be appropriate and it is instead considering its designation as an area of outstanding beauty. The Ministry of Housing and Local Government was not prepared to support the Commission's request for implementation of the proposals drawn up by the Nature Conservancy for an immediate scientific study of the ecological and other factors underlying the problem of preserving the Broads from encroachment.

The report shows that the Commission continues to be deeply concerned as to the adequacy of the arrangements for the administration of the parks and the failure of the Minister to implement the Act. In spite of the Commission's advice that there were no special circumstances in the Yorkshire Dales warranting departure from the form of administration laid down by Parliament as appropriate for multicounty national parks, the Minister has issued a direction under the Act dispensing with the formation of a Joint Board for the Yorkshire Dales National Park. The administrative arrangements for Snow. donia, made in 1953 for an experimental period of three years, have been extended for a further three years, though without objection from the Commis sion; and for reasons the opposite of those given in the case of the Yorkshire Dales, the Minister has also, in accordance with the wishes of the Devon and Somerset County Councils, issued a direction under the Act dispensing with the formation of a joint board for the Exmoor National Park in place of a joint advisory committee. The dubiety of these alternative arrangements is sufficiently illustrated by the Lake District Planning Board's approval, in the face of urgent protests from the National Parks Commission and amenity societies, of a scheme for more than a mile of overhead electricity cable at the head of Great Langdale. The National Parks Commission, in correspondence appended to the report, maintains the view it has consistently expressed that Great Langdale is one of the places of outstanding scenic quality where the whole of the line ought to be laid underground and that the relatively small cost of doing so should be borme by the national undertaking. The Lake District Planning Board, however, has risen to the bait offered by the Electricity Board in the form of a promise of earlier supply if overhead cables were used.

Apart from the concern over such matters and over the large number of aerial masts which are being erected in the countryside for both civilian and military purposes, the Commission has given increased attention to the designation of areas of outstanding natural beauty under Section 87 of the Act. Areas have been designated in the Gower Peninsula, in the Quantocks, in Lleyn and in the Surrey Hills, which

* Seventh Report of the National Parks Commission for the year ending 30th September, 1956. Pp. iv $+66+8$ plates. (London
H.M. Stationery Office, 1956.) 48. net. 